\title{
Classroom-based field experiences in high school STEM academies: opportunities to observe and participate in high-leverage science teaching practices
}

\author{
Stacey L. Carpenter \\ Education Department, University of California, Santa Barbara, CA. 93106-9490
}

\begin{abstract}
In a scholarship program created to recruit and better prepare secondary physical science teachers, undergraduate physics majors had an opportunity to participate in an innovative classroom-based field experience. These field experiences took place in the unique classroom contexts of two STEM-focused academies within traditional public K-12 schools. In this exploratory case study, I examined the opportunities the undergraduates had to observe and participate in high-leverage science teaching practices (HLPs) during the field experience. I also examined the HLPs the undergraduates attended to in their discussions of effective science teaching before and after the experience. The types of HLPs the undergraduates had opportunities to observe and/or participate in during the experience were consistent across the two academy contexts. In particular, undergraduates were most often exposed to the HLP of facilitating classroom talk. Further, undergraduates tended to add HLPs to their visions of effective science teaching after participating. This study provides evidence that STEM academy classrooms as sites for early field experiences can expose potential physics teachers to reform-based teaching.
\end{abstract}

\section{INTRODUCTION}

The Next Generation Science Standards [NGSS][1] and other recent science education reform efforts in the U.S. emphasize student-centered instruction where students engage in science and engineering practices to learn disciplinary core ideas and cross-cutting concepts. These reforms are based on cutting-edge knowledge of how students learn. As such, teachers need to be prepared to teach science in ways aligned with these reforms to best effect student learning. For the preparation of new teachers, classroom-based field experiences are considered crucial because teachers learn in and from the actual practice of teaching and need images of good practice to develop new visions of effective teaching [2, 3]. However, the types of teaching advocated in reform documents, like the NGSS, are often lacking in field experience classrooms [2, 4]. In this exploratory case study, I investigated a unique model for classroom-based field experiences in which undergraduate physics majors participated as interns in classrooms associated with high school STEM academies.

The context for this study was a scholarship program created for undergraduates to explore teaching as a career. Undergraduates majoring in physics had the opportunity to "intern" in STEM academy classrooms. These STEM academies were unique field experience contexts since interns were exposed to innovative physics and engineering teaching and were able to interact with exceptional, awardwinning teachers. Both academies had an engineering component. This is increasingly important and relevant as reforms call for integrating engineering into science instruction [1]. I investigated the internship experiences of four physics majors who participated in the STEM academies of two schools (two interns at each school).
To document the interns' opportunities to observe and participate in reform-based teaching, I used high-leverage teaching practices as an analytic framework. High-leverage teaching practices, also referred to as core practices, are equitable teaching practices that result in student learning, are reasonable for teachers to enact in their first years of teaching, and lay a strong foundation for future teacher learning $[5,6]$. High-leverage practices specific to science teaching can help novice teachers enact reform-based science instruction consistent with the $\operatorname{NGSS}[7,8]$

The following research questions guided this study: (1) What high-leverage science teaching practices did interns have opportunities to observe and/or engage in during the internship? (2) What high-leverage science teaching practices did interns include in their visions of effective science teaching before and after the internship?

\section{METHODS}

\section{A. Study context}

In the internship program, undergraduate physics majors were placed in one of two STEM academies and completed a five-week intensive internship. Since the academic year at the university where the interns were enrolled started five weeks after the K-12 school year began, interns could participate in high school classes five days a week for five weeks. Interns were then given the option of continuing their participation in classrooms throughout the rest of the academic year. Three interns in this study continued to participate, one did not. While both STEM academies were innovative contexts for field experiences, the two academies differed from each other in terms of goals, populations served, curriculum, and organization. 
The Project-Based Engineering Academy (PBEA) was a selective academy (i.e., had admission requirements) that operated within a larger, traditional high school. The PBEA curriculum was collaboratively designed and taught by a team of teachers. Through the academy, PBEA students took one integrated course each year in which they completed authentic engineering projects to facilitate their learning. PBEA students received instruction in physics, computeraided design (CAD)/programming, art, and machining classes on a rotating basis throughout the academic year. Each subject was taught in a dedicated classroom for that subject. The academy referred to these as "spaces." For example, physics was taught in the physics space.

The Green STEM Academy (GSA) also operated within a larger high school, but was a less formal program than PBEA. There was no application process and courses were open to all of the high school's students. GSA students took courses that focused on environmental education, such as Green Engineering, along with core subjects like physics. As an example, in Green Engineering, students learned engineering skills and collaborated on various engineering and environmental projects.

\section{B. Study participants}

In this exploratory case study, I investigated the experiences of four physics majors who participated as interns at the academies. Intern demographic information is shown in Table 1. Erica and Josiah were placed at PBEA. They participated in all aspects of the integrated curriculum for grades 9,10 , and 11 . They were exposed to all four spaces (physics, CAD, art, and machining) and worked with four mentor teachers (one for each space). They participated in three class periods per day (one for each grade level) plus extra time before and after these classes. Quentin and Sung were placed at GSA in physics and Green Engineering classes with one mentor teacher. They participated in four classes per day: Two were college preparatory physics, one was advanced placement physics, and one was Green Engineering. These classes were taught by the same mentor teacher. Program leadership determined the interns' placements. Erica, Josiah, and Quentin continued to participate during the academic year; Sung did not.

\section{Table 1. Intern Demographic Information}

\begin{tabular}{|c|c|c|c|c|}
\hline Intern & Placement & Ethnicity & Gender & $\begin{array}{l}\text { Year at } \\
\text { University }\end{array}$ \\
\hline Erica & PBEA & White & $\mathrm{F}$ & 4 \\
\hline Josiah & PBEA & White & M & $\begin{array}{c}1 \\
\text { (transfer) }\end{array}$ \\
\hline Quentin & GSA & $\begin{array}{l}\text { Chinese } \\
\text { American }\end{array}$ & M & 4 \\
\hline Sung & GSA & $\begin{array}{l}\text { South } \\
\text { Korean }\end{array}$ & M & 2 \\
\hline
\end{tabular}

Note. Ethnicities and genders were self-reported by the interns.

\section{Data collection and analysis}

I used two sources of data for this study: video recordings of classroom participation and intern interviews. For research question 1, I analyzed the video data of classroom instruction. For research question 2, I analyzed the intern interview data. I then compared and contrasted findings between each academy context.

During the five-week intensive, I and research assistants observed and video recorded classes at each academy one to two times per week. Individual interns wore a microphone during recorded class periods to capture dialogue and interactions between the intern and students as well as between the intern and mentor teacher during class time. The microphones also captured teacher talk to the whole class.

Each intern was interviewed individually four times: before the five-week intensive, after the five-week intensive, at the middle of the academic year (in January), and at the end of the academic year (June). Semi-structured interview protocols were used for each interview and included the same questions to elicit interns' ideas about science teaching such as "how do you define effective science teaching" and "how do students best learn science." All interviews were audio recorded, and recordings were transcribed.

Table 2. Codes for High-Leverage Teaching Practices

\begin{tabular}{ll}
\hline Code (HLP) & Description \\
\hline Eliciting student ideas & $\begin{array}{l}\text { Elicits students' mental } \\
\text { models, conceptions, or prior } \\
\text { knowledge about a } \\
\text { phenomenon or topic } \\
\text { Creates explicit opportunities } \\
\text { for students to share } \\
\text { explanations, arguments, ideas, } \\
\text { etc. through whole-class } \\
\text { discussions or group work }\end{array}$ \\
$\begin{array}{l}\text { Facilitating classroom } \\
\text { talk }\end{array}$ & $\begin{array}{l}\text { Frames lesson around } \\
\text { overarching important idea; } \\
\text { makes explicit connection to } \\
\text { big idea during instruction }\end{array}$ \\
$\begin{array}{l}\text { Focusing on big ideas } \\
\text { Focusing on evidence } \\
\text { and/or explanations } \\
\text { evidence-based explanations; } \\
\text { presses students to provide } \\
\text { reasoning and/or evidence }\end{array}$ \\
$\begin{array}{l}\text { Linking concepts and } \\
\text { phenomena }\end{array}$ & $\begin{array}{l}\text { Uses phenomena to help } \\
\text { students make conceptual links } \\
\text { Connects concepts/ phenomena } \\
\text { tonnecting concepts }\end{array}$ \\
$\begin{array}{l}\text { to students' lives and } \\
\text { experiences }\end{array}$ & $\begin{array}{l}\text { Engaging students in } \\
\text { authentic } \\
\text { investigations of } \\
\text { scientific phenomena }\end{array}$ \\
\hline & $\begin{array}{l}\text { Provides opportunities for } \\
\text { students to investigate } \\
\text { phenomena }\end{array}$ \\
\hline
\end{tabular}


For the video analysis for research question 1, I analyzed 10 video recorded class periods for each academy (for a total of 20 class periods). I used the following coding scheme to code each video: First, to organize the coding process and to understand the instructional context in which teaching practices were occurring, I divided each video into segments based on the general structure of student and/or teacher work using the lesson structure codes of individual student work, small group work, teacher talk, interactive lecture, and whole class discussion. These codes were developed from an initial list of provisional codes and then inductively refined through successive rounds of coding [9]. Within these lesson structure segments, I coded for high-leverage practices (HLPs) enacted by mentor teachers and/or interns. HLP codes are shown above in Table 2. I developed these codes based on the scholarly literature on high-leverage, or core, science teaching practices [10-12].

For research question 2, I coded interview transcripts using the following coding scheme: First, I coded each transcript for segments of the transcript that indicated interns' conceptions of effective science teaching. I then coded these segments with the a priori HLP codes (Table 2). To track the HLPs that interns' included in their visions of effective science teaching over time, I created a matrix plotting the presence of HLP codes for each interview (initial, post 5-week intensive, mid-academic year, and endof-year).

\section{FINDINGS}

The frequencies of HLPs observed across the 10 videorecorded class periods for each academy are shown in Table 3. Since HLPs are broad teaching practices (rather than specific teaching actions), if an HLP was present, it typically lasted for the length of the segment in which it was found. For both PBEA and GSA, facilitating classroom talk was the most frequently coded HLP, followed by eliciting students' ideas. Overall, the frequencies of HLP codes were similar between the two academies.

At both PBEA and GSA, teachers most often facilitated classroom talk through small group work. As an example of facilitating classroom talk, the physics teacher at PBEA had students work in pairs to plan and conduct an investigation on magnetism. As students worked in pairs, they had opportunities to share and discuss their ideas. The teacher further emphasized classroom talk by having the pairs of students share their procedures and results with other pairs. She explained, "I want you to know what was going on way over on the other side of the room. So what you're going to do is go talk to somebody. You're going to travel with your pair, you're going to go talk to another pair, and you're going to discuss like, 'Hey, this is what we did. This is what we found." Teachers also facilitated classroom talk during interactive lectures. As an example, the physics/engineering teacher at GSA led students through solving a complex word problem from their homework and had students share out ideas to the whole class and provided time for students to discuss with their neighbors.

Table 3. Frequency of HLP Codes

\begin{tabular}{|c|c|c|}
\hline HLP Code & PBEA & GSA \\
\hline Eliciting student ideas & 6 & 5 \\
\hline Facilitating classroom talk & 19 & 18 \\
\hline Focusing on big ideas & 2 & 0 \\
\hline $\begin{array}{l}\text { Focusing on evidence and/or } \\
\text { explanations }\end{array}$ & 0 & 0 \\
\hline Linking concepts and phenomena & 2 & 5 \\
\hline $\begin{array}{l}\text { Connecting concepts to students' lives } \\
\text { and experiences }\end{array}$ & 4 & 1 \\
\hline $\begin{array}{l}\text { Engaging students in authentic } \\
\text { investigations of scientific phenomena }\end{array}$ & 3 & 4 \\
\hline
\end{tabular}

I analyzed the interview data to determine the highleverage practices that interns included in their visions of effective science teaching throughout the experience (research question 2). Table 4 shows the presence of HLP codes in each interview for each intern.

In general, there was a lack of consistency in the HLPs that interns' discussed across the four interviews. For example, Josiah addressed connecting concepts to students' lives in the initial interview, did not address it in the post five-week interview, addressed it again in the mid-year interview, but did not address it in the end-of-year interview. Only Quentin consistently addressed one HLP across all four interviews (engaging students in investigations). However, this inconsistency is to be expected among novices with developing visions of effective science teaching.

All four interns addressed at least one additional HLP in interviews subsequent to the five-week intensive. Erica did not address any HLPs in her initial interview but addressed a total of four across the subsequent interviews. As an example of an idea aligned with facilitating classroom talk, Erica said, "I really liked how at PBEA [students are] very encouraged [to] work as a family and work as a group. I think that's really helpful to helping students see other ways of learning." Josiah did not address any HLPs in his discussion of effective science teaching in the post five-week intensive interview; however, he addressed additional HLPs in the mid-year and end-of-year interviews. Quentin consistently talked about engaging students in investigations, but it was not until the final two interviews that Quentin added another HLP (connecting concepts to students' lives and experiences). For example, in the end-of-year interview, he described the importance of teaching physics content that is relevant to everyday life such as "basic stuff that is useful to them [students], regardless of who you are...circuitry and lights and cars and stuff." Sung discussed ideas consistent with the HLPs of facilitating classroom talk and eliciting students' ideas in interviews after the 5-week intensive. Overall, interns tended to express more ideas consistent with HLPs after participating in the internship. Three of the four interns discussed facilitating classroom talk in subsequent 
interviews. This was the HLP that occurred most frequently in the analyzed video.

Table 4. HLPs Discussed by Interns in Each Interview

\begin{tabular}{|c|c|c|c|c|}
\hline & : & $\begin{array}{l}\dot{1} \\
\stackrel{n}{0} \\
0 \\
0 \\
0\end{array}$ & 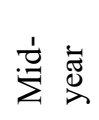 & 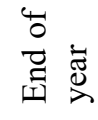 \\
\hline \multicolumn{5}{|l|}{ Erica (PBEA) } \\
\hline $\begin{array}{l}\text { Facilitating classroom } \\
\text { talk }\end{array}$ & & $\mathrm{X}$ & & $\mathrm{X}$ \\
\hline $\begin{array}{l}\text { Engaging students in } \\
\text { investigations }\end{array}$ & & $\mathrm{X}$ & & \\
\hline $\begin{array}{l}\text { Linking concepts \& } \\
\text { phenomena }\end{array}$ & & & $\mathrm{X}$ & \\
\hline Eliciting students' ideas & & & & $\mathrm{X}$ \\
\hline \multicolumn{5}{|l|}{ Josiah (PBEA) } \\
\hline $\begin{array}{l}\text { Connecting concepts to } \\
\text { students' lives }\end{array}$ & $\mathrm{X}$ & & $\mathrm{X}$ & \\
\hline $\begin{array}{l}\text { Facilitating classroom } \\
\text { talk }\end{array}$ & & & $\mathrm{X}$ & $\mathrm{X}$ \\
\hline $\begin{array}{l}\text { Linking concepts \& } \\
\text { phenomena }\end{array}$ & & & $\mathrm{X}$ & \\
\hline \multicolumn{5}{|l|}{ Quentin (GSA) } \\
\hline $\begin{array}{l}\text { Engaging students in } \\
\text { investigations }\end{array}$ & $\mathrm{X}$ & X & $\mathrm{X}$ & $\mathrm{X}$ \\
\hline $\begin{array}{l}\text { Connecting concepts to } \\
\text { students' lives }\end{array}$ & & & X & $\mathrm{X}$ \\
\hline Sung (GSA) & & & & \\
\hline $\begin{array}{l}\text { Facilitating classroom } \\
\text { talk }\end{array}$ & & $\mathrm{X}$ & & $\mathrm{X}$ \\
\hline Eliciting students' ideas & & $\mathrm{X}$ & $\mathrm{X}$ & \\
\hline
\end{tabular}

\section{DISCUSSION}

Four undergraduate physics majors participated as interns in high school STEM academy classrooms to explore teaching as a career. These physics majors had opportunities to observe and participate in high-leverage science teaching practices, particularly the HLP of facilitating classroom talk. The types of HLPs that interns had opportunities to observe and/or participate in during the internship were consistent across the two academy contexts. This is important since prior research has shown that teaching practices aligned with reforms are often lacking in preservice field experience classrooms $[3,5,6]$. This study provides evidence that STEM academy classrooms as sites for early field experiences can expose potential physics teachers to reformbased teaching. However, this was only a small case study of two STEM academies. Further research that examines other STEM academies as contexts for field experiences is needed.

The interns inconsistently addressed HLPs in their discussions of effective science teaching - this is to be expected since the interns were novices with developing visions of effective science teaching. However, after participating in the internship, all four physics majors added ideas consistent with at least one HLP into their "visions" or conceptions of effective science teaching. Factors such as continued participation and length of time spent in classrooms were not considered and are important to examine in future research. For example, Erica, Josiah, and Quentin continued to participate at their placements after the five-week intensive, throughout the academic year, while Sung did not. Continued participation may be important since Josiah and Quentin did not address additional HLPs in their discussions in the post 5-week intensive interview, but did incorporate additional HLPs in later interviews.

This was an exploratory study to provide groundwork for more in-depth analysis. This study did not examine how the interns made sense of HLPs nor how the interns made sense of their experiences. These questions will be explored in future analyses. Further, as a small case study of four interns' participation in two field experience contexts, findings cannot be generalized to larger populations. However, it is promising that the potential physics teachers in this study were able to incorporate ideas aligned with HLPs into their visions of science teaching after participating in innovative classroom contexts where these reform-based, high-leverage teaching practices were apparent.

\section{ACKNOWLEDGMENTS}

Danielle B. Harlow was an advisor to this project. This research was supported by NSF grant 1240075 .

[5] McDonald, M., E. Kazemi, and S.S. Kavanagh, Journal of Teacher Education 64 (5), 378-386 (2013).

[6] Windschitl, M., et al., Science Education 96 (5), 878903 (2012).

[7] Kloser, M., Journal of Research in Science Teaching, 51 (9), 1185-1217 (2014).

[8] http://narst.org/ngsspapers/preservice.cfm. Retrieved $6 / 20 / 2016$.

[9] Saldana, J., The coding manual for qualitative researchers (Sage, Los Angeles, 2013).

[4] Zeichner, K., Journal of Teacher Education 61 (1-2), 8999 (2010). 